\title{
A Molecular Marker Identification Study for Allow Early Selection in Determination Resistant Apple Varieties and Genotypes against to fire blight (Erwinia amylovora)
}

\author{
Emine Orhan (Corresponding author) \\ Ataturk University, Agriculture Faculty \\ Department of Agricultural Biotechnology, 25240 Erzurum, Turkey \\ E-mail: eorhan@atauni.edu.tr \\ Sahin Kaya \\ Ataturk University, Agriculture Faculty \\ Graduate Student, Erzurum 25240, Turkey \\ E-mail: kayashn1@gmail.com
}

\begin{abstract}
The fruit breeding studies require a long process and high costs. Therefore, hybridization and mutation breeding in some countries such as Turkey were thrown into the background. The apple breeding studies in Turkey is generally carried out as a selection breeding. However, since these studies were not carried out in a comprehensive program, most of the selection studies could not be concluded with variety name. In these studies, the characteristics of the genotypes were determined and they could not go further. The marker assisted selection applications are widely used in molecular plant breeding. The DNA markers used in molecular characterization studies are defined as fragments of DNA revealing variations or mutations which can be used to detect polymorphism between different genotypes or alleles of a gene for a particular sequence of DNA in a population. The aim of this study which it was planned as a preliminary study, it has been to identify a molecular marker to help select apple cultivars or genotypes resistant to the fire blight disease agent (Erwinia amylowora). Thus, selection studies will be accelerated and will be possible to determine the variety or genotype which it has the desired properties in a short time. In this study, nine apple varieties (Gala, Ak Sakı, Mondial Gala, Kasel-37, Vista Bella, Starkrimson, Golden Delicious, Royal Gala, Galaxy Gala) were used. A total of nine primers (designed from RLP1 gene sequence) were used to give information about resistance or sensitivity to fire blight. As a result, the information thought to be related to resistance/sensitivity to fire blight was obtained from the agarose gel image of three primer pairs $(\mathrm{E} 1 \mathrm{~F} / \mathrm{E} 1 \mathrm{R}$, E2F/E2R, E2F/E3R).
\end{abstract}

Keywords: Malus, Fire blight, Molecular marker.

DOI: $10.7176 /$ JSTR/5-8-13

\section{Introduction}

The apple is known as the temperate climate fruit type and is found in the genus Malus from the Pomoideae subfamily of the Rosaceae family (Hancock et al. 2008). The fire blight is one of the important diseases affecting the plants of pear, apple and other Rosaceae family (Zwet and Beer 1995). Erwinia amylovora known as the fire blight agent is a bacterium in the Erwinia genus of Enterobacteriaceae family. This bacterium is known with its short-rod-shaped, gram-negative, facultative anaerobe, peritric whip characteristics. Erwinia amylovora causes infection in shoots, flower buds, trunks, roots and main branches and the plants die in a short period of time (Pejchinovski 1996; Hale et al. 1996). In apple, quince and pear gardens have occurred high economic losses in some years due to fire blight. It has been reported that there were 10 million dollars financial losses in New Zealand in 1998. On the other side, about five hundred thousand fruit trees were dismantled in Italy (Vanneste 2000). According to Norelli (2003), more than 220 thousand apple trees (more than 240 hectares) in southwestern Michigan has occured considerable economic losses due to the fire blight. Oktem and Benlioglu (1988) reported that the fire blight disease was first detected in a pear orchard in Afyon Sultandağ first in 1985 in Turkey. It has been reported that pear trees were severely damaged as a result of a severe infection in 1986 and 1987 (Momol et al. 1992). For this reason, in Turkey, it has become more important to detect fire blight-resistant varieties as soon as possible (Ozturk et al. 2011). 
Although many control methods have been tried against to fire blight, a permanent and effective control method has not been developed up until now. The chemicals such as antibiotics and copper have been used as plant control against this disease factor. However, it has been reported that the copper has negative effects especially on the plant physiology and development of the flower (Basim 1999) and that repeated antibiotic use has negative effects on human health and environment (Moller et al. 1981; Bastas ve Sayg1l 2008). Biological control methods are also used for this pathogen disease. The plant breeding studies related to fire blight-resistance has gained importance especially with the development of organic farming. The quarantine is one of the most effective and important methods among the pathogen control methods. However, positive results are obtained when strictly observing the quarantine rules (Zwet and Keil 1979; Maden and Toros 1991). On the other hand, the use of resistant rootstock, intermediate rootstock and cultivars have became more important in the control of fire blight disease (Layne and Quamme 1975).

For a long time, different apple breeding programs against to fire blight have been carried out worldwide. Among these studies, selection and hybridization methods have been widely used. A plant breeding study that will be carried out with classical breeding methods requires a long process such as 6-12 years. In recent years, interest in molecular-level studies has increased, particularly in order to shorten breeding time (Atay et al. 2010). The aim of this study which it was planned as a preliminary study, it has been to identify a molecular marker to help select apple cultivars or genotypes resistant to the fire blight factor. Thus, selection studies will be accelerated and will be possible to determine the varieties and the genotypes which it has the desired properties in a short time.

\section{Materials and Methods}

\subsection{Plant Material}

The leaf samples of apple varieties used in the study were obtained from collection garden at the Department of Horticulture (Atatürk University, Agricultural Faculty). In the spring, the first leaves from the buds of apple trees were brought to the laboratory in cold chain and kept in the freezer $\left(-80^{\circ} \mathrm{C}\right)$ until DNA isolation. In this study, nine apple varieties (Gala, Ak Sakı, Mondial Gala, Kasel-37, Vista Bella, Starkrimson, Golden Delicious, Royal Gala, Galaxy Gala) were used. Some literature studies on resistance or sensitivity of apple varieties against to fire blight are presented in Table 1.

\subsection{Primer design and synthesis}

In this study, the information of fire blight resistance gene determined by Gardiner et al. (2012) was used. This RLP1 gene sequence (Accession No: JN798166) in the NCBI gene bank was used in the primer design. A total of nine primers (four forward and five reverse) were used in this study and a total of twenty primer combinations were tried with this primer pairs. In Table 2, base sequences and $\operatorname{Tm}\left({ }^{\circ} \mathrm{C}\right)$ values of these primer pairs were given.

Table 1. Some literature information about apple varieties used in the study and their resistance or sensitivity against to fire blight

\begin{tabular}{l|l}
\hline Varieties & Resistance/Sensitivity \\
\hline Gala & Very Sensitive (Zwet 1996) \\
& Very Sensitive (Warner 1992) \\
& Moderately Resistant (Vanneste 2000) \\
& Very Sensitive (Hampson and Kemp 2003) \\
& Sensitive (Yllmaz and Aysan 2009) \\
& Sensitive (Kellerhals et al. 2014) \\
& Sensitive (Kost et al. 2015) \\
& Very Sensitive / Sensitive (Koski and Jacobi 2018) \\
& Very Sensitive (Beckerman 2018) \\
& Moderately Resistant (Demir and Gündoğdu 1993) \\
& Moderately Resistant (Akgül et al. 2005; Özçă̆ıran et al. 2004) \\
\hline Ak Sak1 & Moderately Resistant (Demir and Gündoğdu 1993) \\
\hline Mondial Gala & Resistant (Sehic et al. 2009) \\
\hline Kasel-37 & \\
\hline
\end{tabular}




\begin{tabular}{|c|c|}
\hline Starkrimson & $\begin{array}{l}\text { Moderately Resistant (Demir and Gündoğdu 1993) } \\
\text { Sensitive (Koski and Jacobi 2018) }\end{array}$ \\
\hline Golden Delicious & $\begin{array}{l}\text { Very Sensitive (Kleinhampel et al. 1984) } \\
\text { Very Sensitive (Fucikovsky 1987) } \\
\text { Moderately Resistant (Demir and Gündoğdu 1993) } \\
\text { Moderately Resistant (Mirik 2000) } \\
\text { Sensitive (Koski and Jacobi 2018) } \\
\text { Sensitive (Beckerman, 2018) } \\
\text { Resistant (Sehic et al. 2009) }\end{array}$ \\
\hline Royal Gala & Sensitive (Koski and Jacobi 2018) \\
\hline Galaxy Gala & $\begin{array}{l}\text { Moderately Resistant (Akgül et al. 2005; Özçağıran et al. 2004) } \\
\text { Sensitive (Norelli et al. 2003; Turchek 2004) } \\
\text { Sensitive (Kost et al. 2015) }\end{array}$ \\
\hline
\end{tabular}

\subsection{DNA isolation and determination of DNA concentration and purity}

The DNA isolation protocol was carried out in the following steps: $1000 \mu \mathrm{l}$ of DNA extraction buffer (containing $0.2 \%$ of $\beta$-mercaptoethanol and $0.2 \mathrm{~g}$ of PVP) was added to on $0.3 \mathrm{~g}$ plant material in $2 \mathrm{ml}$ tube which is lysed by liquid nitrogen. The tubes were incubated at $65^{\circ} \mathrm{C}$ for 60 minutes. After incubation, 0.4 $\mathrm{ml}$ of chloroform was added and the tubes were centrifuged at $14.000 \mathrm{rpm}$ for 20 minutes $\left(+4^{\circ} \mathrm{C}\right)$. The supernatant was transferred into a new tube and added $2.5 \mu \mathrm{l}$ of RNase and $8 \mu \mathrm{l}$ of proteinase-K and incubate for 45 minutes at $37^{\circ} \mathrm{C}$. To precipitate the DNA, $100 \mu \mathrm{l}$ ammonium acetate and two and a half times the volume of isopropanol are added to each tube. The tubes were centrifuged at $14.000 \mathrm{rpm}$ for 20 minutes and were centrifuged again for 1 minute. The DNA was then washed with $70 \%$ ethanol and dissolved in $100 \mathrm{ml}$ of $1 \mathrm{X}$ TE buffer. The DNA was suspended at $+4^{\circ} \mathrm{C}$ for 24 hours and stored at $(-) 20^{\circ} \mathrm{C}$. DNA quantity and purity of the samples were determined. For this, 260 (OD260) and 280 (OD280) nanometer optical densitometric spectrophotometer nanodrop readings were made. Then, DNA concentrations were equalized.

Table 2. Base sequences and $\operatorname{Tm}\left({ }^{\circ} \mathrm{C}\right)$ values of primer pairs used in this study (F: Forward primer, R: Reverse primer)

\begin{tabular}{lll}
\hline Primer name & Primer sequence $\left(\mathbf{5}^{\prime} \rightarrow \mathbf{3}^{\prime}\right)$ & Tm $\left({ }^{\circ} \mathbf{C}\right)$ \\
\hline E1F & TCCGAATCCTTGACCTCATC & 60,01 \\
\hline E1R & AGGTGGTTGTGGCTCAAATC & 59,97 \\
\hline E2F & ACCGCCCAGTTTAATTGTATC & 60,00 \\
\hline E2R & TTGTGGCTCAAATCTAAGTGC & 60,00 \\
\hline E3F & TTCCTTGAACCAGCTTTCG & 58,98 \\
\hline E3R & AAGACGACGCTTCAAGGTG & 59,02 \\
\hline E4F & ACTTTATCACCGGTACCATC & 54,00 \\
\hline E4R & TTGTGGCTCAAATCTAAGTG & 53,97 \\
\hline E5R & TTGTTGCAATCGAGATTTAG & 53,92 \\
\hline
\end{tabular}

\subsection{PCR and electrophoresis procedures}

PCR content was prepared in $22 \mu 1$ total reaction volume; $12.5 \mu 1 \mathrm{dH} 2 \mathrm{O}, 1 \mu 1$ genomic DNA, $0.5 \mu 1 \mathrm{dNTP}, 2 \mu 1$ $1 \times P C R$ buffer, $2.5 \mu 1 \mathrm{MgCl}_{2}$ and $0.5 \mu 1$ Taq polymerase and $1 \mu 1$ each primer (forward and reverse primers). The PCR cycle was based on the following steps; 5 minutes at $94^{\circ} \mathrm{C}, 1$ minutes at $94{ }^{\circ} \mathrm{C}+1$ minutes at 45 $60^{\circ} \mathrm{C}+1$ minutes at $72{ }^{\circ} \mathrm{C}(45$ cycles $)$ and lastly 5 minutes at $72{ }^{\circ} \mathrm{C}$. The PCR products were run on agarose gel electrophoresis. Agarose gel was prepared with SB (sodium borate) buffer in $1 \%$ concentration. 
Ethidium bromide was added in the amount of $0.5 \mathrm{mg} / \mathrm{ml}$ into the agarose gel. The electrophoresis process was carried out for 150 minutes at 70 volts. The gel was examined and photographed under UV light on the imaging device. For evaluation, a 1 kb DNA marker on the gel was used.

\section{Results}

A total of nine primers were used to give information about resistance or sensitivity to fire blight (Erwinia amylowora) and the agarose gel images of these primer pair combinations were given below. Agarose gel images of E1F/E1R, E2F/E2R and E2F/E3R primer combinations showed significantly different band images. In Figure 1a, a single band were obtained (approximately 90 b) for Kasel-37 and Galaxy Gala apple varieties used in the E1F/E1R primer pair gel image, while three bands (approximately 90bp, 150bp and $220 \mathrm{bp}$ ) for Gala, Ak Sakı, Mondial Gala, Vista Bella, Starkrimson, Golden Delicious and Royal Gala varieties were obtained. In the E2F/E2R primer pair gel image, a single band (70 bp) was obtained in Kasel37 and Galaxy Gala apple varieties (Figure.1b). In addition to, two bands in Gala and Golden Delicious apple varieties were seen at approximately $70 \mathrm{bp}$ and $175 \mathrm{bp}$, while in the other apple varieties (Ak Sak1, Mondial Gala, Kasel-37, Vista Bella, Starkrimson, Royal Gala, Galaxy Gala) three bands of approximately 70bp, 175bp and 200bp were obtained (Figure.1b). In the gel image of the E2F/E3R primer pair (Figure.1c), a clear band of approximately $280 \mathrm{bp}$ in Ak Sakı, Mondial Gala, Vista Bella, Starkrimson, Golden Delicious and Royal Gala apple varieties were obtained according to Gala, Kasel-37 and Galaxy Gala apple varieties. In other combinations of primer pairs, there was no band image which would show any difference to the resistance of apple varieties for fireblight disease.

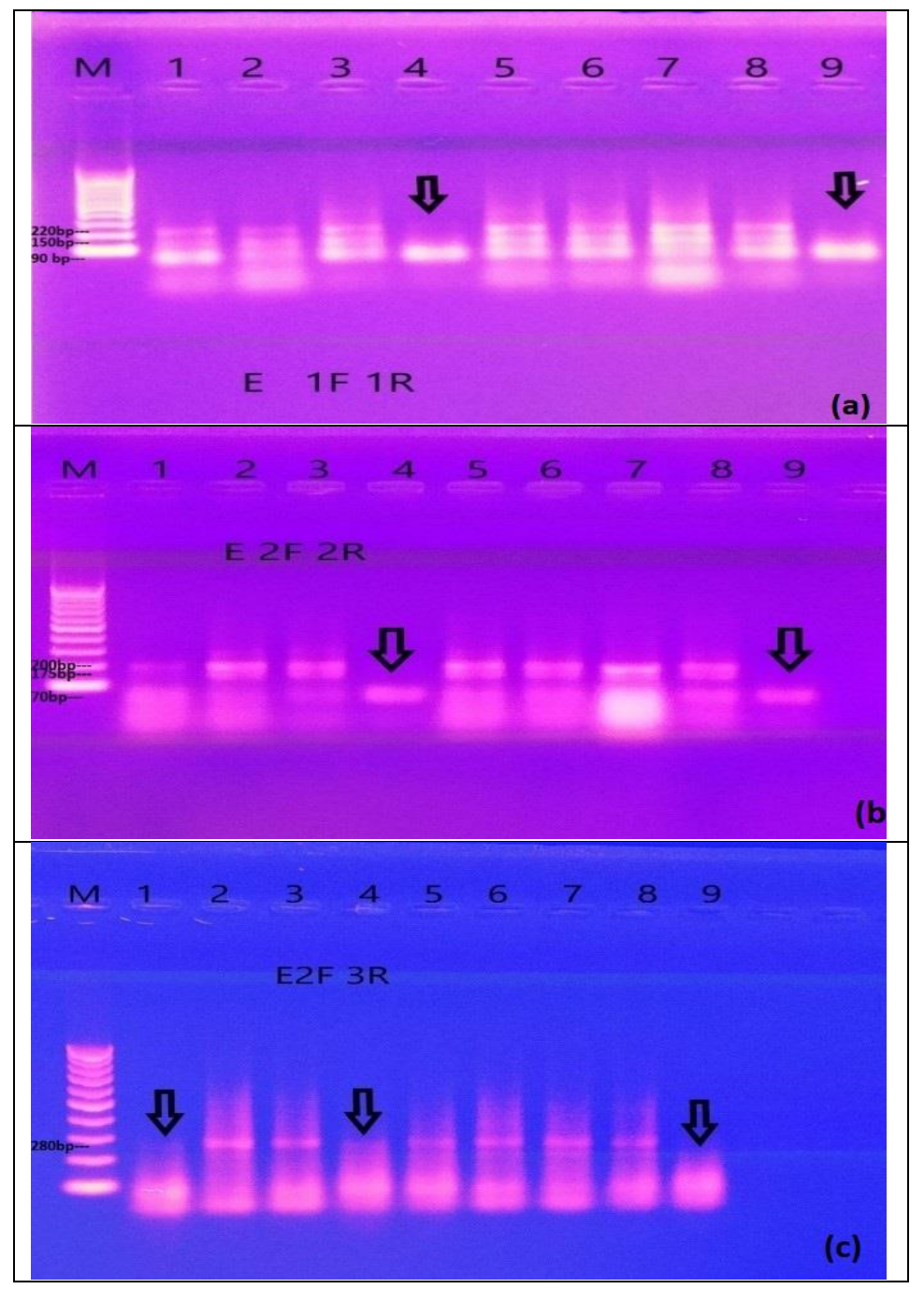

Figure 1. Agarose gel image of E1F/E1R (a), E2F/E2R (b) and E2F/E3R (c) primer pairs (M:Marker, 1:Gala, 2:Ak Sak1, 3:Mondial Gala, 4:Kasel-37, 5:Vista Bella, 6:Starkrimson, 7:Golden Delicious, 8:Royal Gala, 9:Galaxy Gala) 


\section{Discussions}

The selection has been one of the most important steps in apple cultivation and many of the apple varieties described so far have been evaluated. However, many countries except Turkey, has given more importance to hybridization breeding and has developed numerous varieties and rootstocks that were determined to be appropriate to their ecology (Kacal et al. 2009; Atay et al. 2010). On the other hand, vegetative propagation is preferred in order to maintain the genetic structure of perennial fruit species such as apple species. The apple breeding studies are quite difficult and requires a long period of youth infertility and large growing areas. Moreover, the high annual maintenance costs in these growing areas make the breeding studies harder. In recent years, DNA-based molecular methods have been used more in order to obtain results in plant breeding studies in less time. The use of molecular markers related to fruit quality and yield-related characters and disease resistance allows early selection. The most important issue in all breeding programs applied in fruit species was related to resistance to diseases.

In this study which was planned as a preliminary study, a gene sequence (RLP1 gene; Gardiner et al. 2012) which was found to be associated with resistance to fire blight was utilized. The primers intended to be considered as molecular marker candidates were designed from this gene sequence and were screened in nine apple cultivars (Gala, Ak Sak1, Mondial Gala, Kasel-37, Vista Bella, Starkrimson, Golden Delicious, Royal Gala and Galaxy Gala). As a result, the information thought to be related to resistance/sensitivity to fire blight was obtained from the agarose gel image of three primer pairs (E1F/E1R, E2F/E2R, E2F/E3R). As a result of the use of the E1F/E1R primer pair, the Kasel-37 and Galaxy Gala apple varieties showed a distinctly different band from the band images of the other apple varieties (Gala, Ak Sak1, Mondial Gala, Vista Bella, Starkrimson, Golden Delicious, Royal Gala) (Figure 1a). Similarly, in the use of the E2F/E2R primer pair, the band image of Kasel-37 and Galaxy Gala apple cultivars were differed from the band images of other apple cultivars (Figure 1b). In addition, as a result of the use of the same pair of primers (E2F/E2R), Gala and Golden Delicious apple varieties were observed to produce a band of very little difference which could be distinguished from other apple varieties (Figure 1b). On the other hand, as a result of using E2F/E3R primer pair (Figure 1c), band image of Gala, Kasel-37 and Galaxy Gala apple varieties were found different from other apple varieties (Ak Sak1, Mondial Gala, Vista Bella, Starkrimson, Golden Delicious, Royal Gala).

In this study, the literature on the resistance/susceptibility of apple cultivars to fire blight is given in Table1. The information in this table is generally based on the results of phenotypic analysis. Moreover, it should be known that; the resistance to fire blight and the degree of sensitivity changed even in year-to-year climate conditions (Koski and Jacobi 2018).

According to the information in Table1, Kasel-37 and Galaxy Gala apple varieties are expressed in moderate resistance while Gala apple variety is very sensitive and sensitive (Zwet 1996; Warner 1992; Hampson and Kemp 2003; Y1lmaz and Aysan 2009; Kost et al. 2015; Beckerman 2018; Koski and Jacobi 2018). In a gene transfer study by Kellerhals et al. (2014), has been mentioned to transfer the resistance gene from 'Malus X robusta' wild apple plant to 'Gala' apple variety, which is susceptible to fire blight. In a study on a gene transfer (Kost et al. 2015), it has stated that Galaxy Gala apple cultivar was a sensitive species against Erwinia amylovora by Norelli et al. (2003) and (Turchek 2004). Gala and Royal Gala varieties are expressed as apple varieties obtained by Kidd's Orange Red x Golden Delicious hybridization (Kiddle 2006). 'Galaxy Gala' is an apple variety that is cultivated as a natural mutation of the 'Royal Gala' apple tree which is one of the Gala group apple varieties (Kiddle 2006). In a molecular study (Sehic et al. 2009), as a result of the AE10-375 and GE-8019 SCAR primers, Vista Bella variety was found to be resistant to fire blight (Khan et al. 2007). On the other hand, 'Golden Delicious' variety was reported to be fireblight-resistant only with the SCAR primer named AE10-375 (Khan et al. 2007). Because the DNA based molecular markers provide more accurate information than morphological and phenotypic evaluations, the following assessments can be made. In this study, according to the agarose gel images obtained from E1F/E1R, E2F/E2R and E2F/E3R primer pairs, the band information observed in Vista Bella, Golden Delicious apple varieties is similar to the band information belonging to Ak Sak1, Mondial Gala, Starkrimson and Royal Gala. Because of these results, it can be mentioned that these apple varieties contain fire blight-resistance gene sequence. Thus, if an explanation is made based on agarose gel images according to E1F/E1R and E2F/E2R; probably Kasel37 and Galaxy Gala apple varieties are sensitive and other apple varieties give an impression of resistance against the Erwinia amylovora. On the other hand, Ak Sak1, Mondial Gala, Vista Bella, Starkrimson, Golden Delicious, Royal Gala apple varieties can be expressed as fire blight-resistant, while Gala, Kasel-37 and Galaxy Gala apple varieties can be expressed as fire blight-sensitive according to the agarose gel image of E2F/3R pirmer pair. The different sources indicate that Gala apple variety is very sensitive or sensitive to fire blight. For the Gala variety; the E2F/3R image differed from the E1F/1R and E2F/2R images. It has thought that this variety may be related to different allele hosting as a description of this situation. As a 
result, the information thought to be related to resistance/sensitivity to fire blight was obtained from the agarose gel image of three primer pairs (E1F/E1R, E2F/E2R, E2F/E3R). Following this study, a comprehensive study has planned in different fruit species such as apple, pear and quince which are highly affected by this disease factor.

\section{Acknowledgements}

The plant material used in this study was obtained from the Apple Collection Garden at Department of Horticulture (Atatürk University, Agricultural Faculty). We would like to thank Prof. Dr. Rafet Aslantas who contributed to this apple collection and Asst. Prof. Gursel Ozkan for helping to provide samples. This study was supported by Atatürk University Scientific Research Projects Coordination Unit.

\section{References}

Atay, N., Atay, E., Koyuncu, F. (2010). Dünya Elma Islah Programlarına Genel Bir Bakış (Derleme). Bahçe, 39(1):31-44

Basım, H. (1999). Erwinia amylovora İzolatlarının Streptomisin ve Bakır'a Dayanıklılıkları ve Plazmid Profilleri. Su Ürünleri Ziraat Fakültesi Dergisi, 12 (17):22-30

Bastas, K.K., Saygılı, H. (2008). Ateş Yanıklığı Hastalığı, Fire Blight, Erwinia amylovora. Bitki Bakteri Hastalıkları Kitabı (Ed: Saygılı H., Şahin, F. ve Aysan, Y.), 61-68

Beckerman, J. (2018). Fruit Diseases: Disease Susceptibility of Common Apple Cultivars, BP-132W. [Online] Available: https://www.extension.purdue.edu/extmedia/BP/BP-132-W.pdf

Gardiner, S.E., Norelli, J.L., Silva, N., Fazio, G., Peil, A., Malnoy, M., Horner, M., Bowatte, D., Carlisle, C., Wiedow, C., Wan, Y., Bassett, C.L., Baldo, A.M., Celton, J.M., Richter, K., Aldwinckle, H.S., Bus, V.G.M. (2012). Putative Resistance Gene Markers Associated with Quantitative Trait Loci for Fire Blight Resistance in Malus 'Robusta 5' Accessions. BMC Genetics, 13, 25

Hale, C.N., Taylor, R.K., Clark, R.G., Batchelor, T.A. (1996). Quarantine and market access, Fire Blight (Erwinia amylovora), Some Aspects of Epidemiology and Control, P. Sobiczewski, T. Deckers, and J. Pulawska (Eds.), Research Institute of Pomology and Floriculture, Skierniewice, 84 p, Poland.

Hampson, C.R., Kemp, H. (2003). Characteristics of Important Commercial Apple Cultivars. In Apples Books, CABI Publishing, Cambridge, 61-89

Hancock, J.F., Luby, J.J., Brown, S.K., Lobos, G.A. (2008). Apples (Chapter 1). [Online] Available: https://www.researchgate.net/publication/257826786

Kacal, E., Ozturk, G., Atay, N., Sarisu, C., Ozongun, Ş., Atay, E., Emre, R.A., Yurekli, O. Karamursel, O. F. (2009). Eğirdir Bahçe Kültürleri Araştırma Enstitüsü Elma Islah Çalışmaları. Tarım Bilimleri Araştırma Dergisi, 2 (1):57-60

Kellerhals, M., Schutz, S., Baumgartner, I.O., Schaad, J., Kort, T., Broggini, G., Patocchi, A. (2014). Breeding Fire Blight Resistant Apple Varieties. Agrarforschung Schweiz, 5(10):414-421

Khan, A.M., Durel, C.E., Duffy, B., Drouet, D., Kellerhals, M., Gessler, C., Patocchi, A. (2007). Development of Molecular Markers Linked to the 'Fiesta' Linkage Group 7 Major QTL for Fireblight Resistance and Their Application for Marker-Assisted Selection. Genome, 50:568-577

Kiddle, K.W. (2006). Apple (Malus Mill.): Galaxy. Plant Varieties Journal, 59(1-2)

Koski R.D. and Jacobi W.R. (2018). Fire Blight 2907. Colorado State University Extension. [Online] Available: http://extension.colostate.edu/topic-areas/yard-garden/fire-blight-2-907/(20.06.2018)

Kost, T. D., Gessler, C., Jansch, M., Flachowsky, H., Patocchi, A., and Broggini, G. A. (2015). Development of The First Cisgenic Apple With Increased Resistance To Fire Blight. Plosone. 10(12), Article Number: e0143980 
Layne, E.C., Quamme, H.A. (1975). Advances in Fruit Breeding, ed: Janick. J. and Moore, J., 39-70

Maden, S., Toros, S. (1991). Tarımsal Savaşım ve Yöntemleri. Ankara Üniversitesi Ziraat Fakültesi Yayınları, Ankara.

Moller, W.J., Schroth, M.N. and Thomson, S.V. (1981). The Scenario of Fire Blight and Streptomycin Resistance (Erwinia amylovora; California; USA), Plant Diseases, 65:563-68, USA.

Momol, T.M., Yeğen, O., Basım, H., Rudolph, K. (1992). Identification of Erwinia amylovora and The Occurance of Fire Blight of Pear in Western Mediterranean Region of Turkey. Journal of Turkish Phyto. 21(1):41-47

Norelli, J.L., Jones, A.L., Aldwinckle, H.S. (2003). Fire Blight Management in The Twenty First Century: Using New Techniques That Enhance Host Resistance in Apple. Plant Disease, 87:756-765

Oktem, Y.E., Benlioğlu, K., (1988). Yumuşak Çekirdekli Meyve Ağaçlarında Görülen Ateş Yanıklığ Hastalık Etmeni (Erwinia amylovora (Burr.)) Üzerinde Çalışmalar, Türkiye Fitapatoloji Kongresi (Antalya), 71

Öztürk, G., Basım, E., Basım, H., Emre, R.A., Karamürsel, Ö.F., Eren, İ., İşçi, M., Kaçal, E. (2011). Kontrollü Melezleme Yoluyla Ateş Yanıklığı (Erwinia amylovora) Hastalığına Karşı Dayanıklı Yeni Armut Çeşitlerinin Geliştirilmesi: İlk Meyve Gözlemleri. VI. Bahçe Bitkileri Kongresi, 04-08

Pejchinovski, F.D. (1996). Fire blight in Republic of Macedonia (distribution and control), Fire Blight (Erwinia amylovora), Some Aspects of Epidemiology and Control, P. Sobiczewski, T. Deckers, and J. Pulawska (Eds.), Research Institute of Pomology and Floriculture, Skierniewice, 84 p, Poland.

Sehic J., Nybom H., Garkava Gustavsson L., Patocchi A., Kellerhals M., Duffy B. (2009). Fire Blight (Erwinia amylovora) Resistance in Apple Varieties Associated With Molecular Markers. International Journal of Horticultural Science, 15 (1-2). [Online] Available: https://www.researchgate.net/publication/280133447Fire_blight_Erwinia_amylovora_resistance_in apple_varieties_associated_with_molecular_markers $(3 \overline{0} .06 .20 \overline{1} 8)$

Turchek W.W. (2004). Apple Diseases and Their Management. In: Naqvi SAMH, editor. Diseases of Fruits and Vegetables. Springer, pp. 35-35

Vanneste, J.L. (2000). What is Fire Blight? Who is Erwinia amylovora? How to Control It. pp 1-6. In: Fire Blight. The Disease and its Causative Agent, Erwinia amylovora. Edited by J.L. Vanneste. CABI Publishing, UK 2000.

Warner, J. (1992). Field Susceptibility of 68 Apple Cultivars to Cedar Apple Rust, Quince Rust and Hawthorn Rust. Fruit Varieties Journal, 46:6-10

Yılmaz, M.A., Aysan, Y. (2009). Erwinia amylovora'nın Neden Olduğu Ateş Yanıklığı Hastalığının Elmalardan Izolasyonu, Belirtileri, Yayılması ve Mücadelesi. Tarım Bilimleri Araştırma Dergisi, 2(1):75-77

Zwet, T., Keil, H.L. (1979). Fire Blight a Bacterial Disease of Rosaceous Plants. Agriculture Handbook, USA Dept. of Agr, Washington: 200, 510

Zwet, T. (1992). Worldwide Spread and Present Distribution of Fire Blight- An Update, Acta Hort., 338, 2931

Zwet, T., Beer, S.V. (1995). Fire Blight-Its Nature, Prevention, and Control. A Practical Guide to Integrated Disease Management, US Department of Agriculture, Agriculture Information Bulletin, 91. 